\title{
The influence of social support and social skills on the academic performance of younger individuals and older adult college students
}

\author{
A influência do apoio social e das habilidades \\ sociais no desempenho acadêmico dos \\ universitários jovens e idosos
}

\author{
Soniárlei Vieira LEITE ${ }^{1}$ (DD) 0000-0002-5587-3787 \\ Lucia Helena de Freitas Pinho FRANÇA² ID 0000-0003-0676-3757

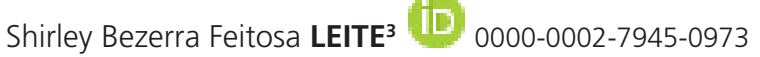

\begin{abstract}
The ageing process has provoked a visible increase of older adult students in Brazilian universities. Several studies have been conducted on the development of this older adult student, but few have tested the influence of social skills and perceived social support on academic performance by comparing different age groups. The goal of this longitudinal study was to investigate the influence of social support and social skills on the academic performance of older adult college students compared to younger individuals. The sample was composed of 326 college students (200 younger individuals and 126 older adults), from 13 universities in the metropolitan area of the city of Rio de Janeiro. Multiple hierarchical regression confirmed the predictive power of the social support (but not the social skills) over academic performance. The evolution of academic performance (performance coefficient) was observed for two years. New studies with larger samples in other regional contexts are recommended.
\end{abstract}

Keywords: Academic achievement; Ageing; Social skills; Social support.

\section{Resumo}

O processo de envelhecimento provocou um visivel aumento da quantidade de estudantes idosos nas universidades brasileiras. Diversas pesquisas foram realizadas sobre o desenvolvimento deste estudante idoso, mas poucos estudos

$\boldsymbol{v V} \boldsymbol{v}$

1 Universidade Veiga de Almeida, Centro de Ciências Jurídicas e Sociais, Curso de Direito. Rio de Janeiro, RJ, Brasil.

2 Universidade Salgado de Oliveira, Programa de Pós-Graduação em Psicologia. R. Marechal Deodoro, 211, bloco C, $2^{\circ}$ andar, Centro, 24030-060, Niterói, RJ, Brasil. Correspondence to: L.H.F.P. FRANÇA. E-mail: <lucia.franca@gmail.com>.

${ }^{3}$ Pesquisadora autônoma. Rio de Janeiro, RJ, Brasil.

Article based on the thesis of S.V. LEITE, entitled "A influência da relação intergeracional, do apoio social e das habilidades sociais no desempenho dos universitários jovens e idosos”. Universidade Salgado de Oliveira, 2017.

$\boldsymbol{\nabla} \mathbf{\nabla}$

How to cite this article

Leite, S. V., França, L. H. F. P., \& Leite, S. B. F. (2021). The influence of social support and social skills on the academic performance of younger individuals and older adult college students. Estudos de Psicologia (Campinas), 38, e190146. https://doi.org/10.1590/1982$0275202138 \mathrm{e} 190146$ 
testaram a influência do apoio social percebido e das habilidades sociais no desempenho acadêmico deles em comparação com estudantes de outras faixas etárias. O objetivo deste estudo longitudinal foi investigar a influência do apoio social e das habilidades sociais sobre o desempenho acadêmico dos estudantes universitários idosos em comparação aos jovens. A amostra foi composta por 326 universitários (200 jovens e 126 idosos) de 13 instituições universitárias da região metropolitana do Rio de Janeiro. A regressão múltipla hierárquica confirmou o poder preditivo do apoio social, mas não das habilidades sociais sobre o desempenho acadêmico. A evolução do desempenho acadêmico (medida através do coeficiente de rendimento escolar) dos universitários que compunham a amostra foi observada durante dois anos. São recomendados novos estudos com amostras maiores em contextos regionais.

Palavras-chave: Desempenho acadêmico; Envelhecimento; Habilidades sociais; Apoio social.

The transition to college life can bring external and internal conflicts to students, especially when they face new opportunities and challenges. In this process of dealing with the outside world in the face of new personal and institutional relationships, these students learn to make internal adjustments, both by identifying themselves with social roles, and by learning new knowledge from the college life. Thus, the simple choice of a college course and the consequent tests and exams cause an extreme inner struggle, acute in all students (Chaves et al., 2016).

With the population ageing process, an increasing number of older adults - using the United Nations definition of older adults (Organização das Nações Unidas, 2003) for those aged 60 or over - who are interested in entering college (Wiles, Leibing, Guberman, Reeve, \& Allen, 2012). Thus, the choice of a course represents a great challenge also for older adult students, since they will inevitably make internal comparisons about their intelligence, in parallel with younger students (Ardelt, 2010), and will also be compared to these by society.

The transition to college involves a notable increase in the level of stress for most college students (Thurber \& Walton, 2012). Social support is a potential stress reducer, and its relevance for a successful adaptation to the college environment has been investigated (Roberts \& Dunbar, 2015). More than 40 years ago, researchers became interested in the effect of social relationships on people's health and highlighted that relationships, in general, predict health and social adaptation, reducing stress, mortality, among other effects.

About social support, according to Sherbourne and Stewart (1991), this construct is defined as the resources made available for other people in situations of need. These authors point out five factors that make up social support: material, affective, positive social interaction, emotional, and informational. Griep, Chor, Faerstein, Werneck, and Lopes (2005), who are Brazilian researchers, highlighted that social support is a functional or qualitative dimension of the social network.

Neri (2014) made no distinction when he conceptualized social assistance and social support as a product of social relationships and the way in which the individual perceives the quality, frequency, and adequacy of the assistance offered in view of his needs. However, for the sake of textual consistency and in order not to confuse the reader, the term "social support" will be used in this study.

Several studies have shown that social and family support is positively related to college performance (Sultan \& Raschid, 2015). There is also consistent evidence that the reduced social support perceived by students is related to a lack of persistence (Mertoglu \& Aydin, 2012), and learning and behavioral problems (Bandeira, Rocha, Freitas, Del-Prette, \& Del-Prette, 2006).

Not only social support, but social skills also seem to exert a protective factor for good academic results, being a predictor of positive results in the development of students with learning difficulties compared to those with satisfactory academic performances (Morrison, 2015). Those with difficulties are usually considered less popular, less cooperative, less empathic, with poorer verbal and non-verbal qualities, and are neglected by their peers (Mirabelli, 2015). However, the empirical association between low social ability, low social

2 support, and low academic performance is still not evident. 
Since the mid-1970s, successive criticisms of the definitions have emerged, invariably following the path of giving greater relevance to the assertiveness of social responses, as a way of defining the construct (Del Prette, A. \& Del Prette, Z., 2018). Studies carried out by Rocha and Carreira (2011) indicate that social skills are important for the formation and maintenance of positive social relationships, and fundamental for the understanding of the exercise of rights and duties. Social skills are relevant to quality of life and health: the positive relationships between the social skills, quality of life, professional and personal satisfaction, as well as difficulties in social interaction variables are related to a series of psychological spectrum disorders (Bonaco, Costa, Gon, \& Zamignani, 2019).

In Brazil, the scholars who have most investigated the Social Skills construct are Del Prette, Z. and Del Prette, A. (2001, 2009, 2018). According to Del Prette, A. and Del Prette, Z. (2018) social skills represent a set of behaviors emitted by the individual due to demands resulted from a personal situation, in order to maximize gains and reduce losses among those who socially interact.

Social skills relate to the existence of different social behavior patterns, so that an individual can deal with various interpersonal situations. The healthiest and most productive individuals are least prone to diseases and are those who demonstrate good interpersonal relationships (Del Prette, Z., Del Prette, A., \& Barreto, 2006). Social Skills can be organized into classes: communication skills; civility skills, assertive in coping with rights and citizenship; empathic skills and positive feeling expression; professional social skills; educational social skills of parents, teachers, or other education agents; and self-monitoring skills.

Self-monitoring skills are related to the general ability to observe, describe, interpret, and regulate thoughts, feelings, and behaviors in social situations (Del Prette, Z. \& Del Prette, A., 2009). The authors promoted training, interventions, and extension courses in the provision of services to the community with regard to Social Skills.

With the premise that the teaching-learning process is based on personal nature, Eisenhower, Baker, and Blacherr (2007) pointed out that social skills have an instrumental function for academic learning. In other words, to be successful in this process, the student must formulate and answer questions, participate in debates, know how to request help, among other skills. In spite of the research developed by Del Prette, Z. and Del Prette, A. $(2001,2006,2009,2018)$, there is a scarcity of studies that prove that social skills can promote academic success or act in a reverse way.

The literature has indicated that the socio-emotional development of students may be associated with their repertoire of social skills and perceived social support, while the failure experience seems to negatively influence this development and performance (Fernandes, Lemes, Elias, \& Soares, 2018). In fact, socio-cognitive and socio-emotional variables have influenced the adaptation process to higher education and the academic performance (Cerda et al., 2015). Skills such as perseverance, collaboration, and responsibility can help students in their academic performance and in their everyday activities (Ambiel, Pereira, \& Moreira, 2015).

In the study of generations, the differences between the age groups are visible, perceived in the differences in the discourses of young people and older adults, their values, social relations, family dependence and independence, a sense of responsibility towards their actions, and the different reactions towards technology, among others. In the case of older adult students, their participation in the college environment allows them to develop a connection between social contact, social support, and longevity (Brito \& Pavarini, 2012), as well as achieving a positive feeling of belonging. In addition, the institution can have crucial role of supporting the older adult student by providing tools for an honest, generous, and fair existence, which covers both material and spiritual aspects. Higher education is a vehicle for deepening and strengthening self-determination for the intellectual emancipation of human beings (Rudnick et al., 2013).

These generations can represent a differentiating factor regarding academic performance; also provided by the different types of emotional, instrumental, and cultural support received throughout life. A study 
with American college students demonstrated that the educational level of their parents and grandparents could influence the independence and academic performance of these college students (Stephens, Fryberg, Markus, Johnson, \& Cavarrubias, 2012).

Despite these findings, there is a gap in the literature regarding studies that investigate the influence of social support and social skills on academic performance in different age groups. Bauman (2011), in a critical view on young people and the educational system, emphasizes that the current educational model reproduces the privileges between generations and the majority of college students at the most competitive American universities come from rich families and only 3\% come from poor families. In a fluid and fast scenario, with unpredictable changes, education needs to be considered throughout life. For this author, the online social network that meets the fear young people have of being abandoned, ends up facilitating the loss or non-acquisition of social skills that could and should help them to solve our fears that originate in the offline world. The generations vary according to values, beliefs, and social, economic, environmental, family, cultural, and educational standards, among others.

Undoubtedly, it is important to build a multidimensional model that aggregates the different variables that must be involved in the assessment of academic performance and the different generations. However, the scope of this study was restricted to investigating two important variables: social skills and social support, and whether they would influence the academic performance of younger individuals and older adult college students.

The goal of this study was to investigate the influence of social support and social skills on the academic performance of older adult students, compared to younger ones at universities in the city of Rio de Janeiro, Brazil. Their performance was measured over three years. Based on the literature review presented, two hypotheses were tested. The first hypothesis is that social support would positively influence academic results, especially for older adults. The second hypothesis is that social skills would positively influence academic performance for both age groups.

\section{Method}

The study adopted a quantitative approach with a longitudinal cohort, investigating whether social support and social skills would influence the academic performance of younger individuals and older adults in three different periods. Thus, the influence of the independent variables (social support and social skills) on the dependent variable (academic performance) was analyzed, comparing the respective effects on the two age groups (younger individuals and older adults) in three different periods. It is important to note that this manuscript is part of a larger study carried out by the first author in his doctoral thesis, whose data have already been partially published (Leite \& França, 2018). Thus, more detailed data on the contents of the exploratory scales will be briefly described here.

\section{Participants}

It was used a sample for convenience, which consisted of 326 participants, 126 of whom were older adult students (60 years old or more) and 200 younger students (18 to 25 years old) enrolled in 13 public and private higher education institutions located in the metropolitan area of the city of Rio de Janeiro, Brazil. The students were invited to participate in the research after the main author and the third author visited these institutions and having agreed upon the application of the research among those who met the criteria described above. The total number of guests was 500 students, with a positive

4 feedback of 326 of them. 


\section{Instruments}

The instruments used were: The Medical Outcomes Study Social Support Survey (MOS-SSS) social support scale (Sherbourne \& Stewart, 1991), adapted and validated for use in Brazil by Griep et al. (2005) and the Social Skills Inventory (SSI-Del-Prette) (Del Prette \& Del Prette, 2001). Regarding academic performance, the students' Performance Coefficients (PC) were analyzed, obtained in the academic systems of the educational institutions surveyed between 2014 and 2016, that is, PC1, PC2, PC3, and Total PC (sum of PC divided by 3).

\section{Social Skills Inventory}

To measure the social skills of the sample made up of younger individuals and older adult college students, the SSI-Del-Prette, a self-applicable instrument, was used. It consists of 38 items, grouped in five dimensions, which describe an interpersonal relationship and a possible reaction to the situation described. A 5-item Likert Scale was used. The respondent has to estimate the relative frequency with which he or she acts or reacts in the described manner, as follows: 0 ("never"), 1 ("rarely"), 2 ("sometimes"), 3 ("almost always") and 4 ("always"). The general score consists of the sum of the gross values for the items, and ranges from zero to 100 points. The SSI-Del-Prette (Del Prette \& Del Prette, 2001) is subdivided into five dimensions: D1 - Coping and self-assertion to risk. D2 - Self-assertion in the expression of positive feelings; D3 - Conversation and social resourcefulness; D4 - Self-exposure to strangers and new situations; and D5 - Self-control of aggression.

The Social Skills Inventory (SSI1) - (Del Prette \& Del Prette, 2001), with 38 items, was fully applied with the present group of older adults and younger individuals. Exploratory and confirmatory factor analysis showed problems in maintaining items whose factor loads $<0.04$. Even adjusting the model using the Factor and MPlus computer programs, these rates were not good in the confirmatory factor analysis. Thus, the best fit was the adoption of a brief and one-dimensional scale with 13 items. The Kaiser-Meyer-Olkin was 0.776, the Barlett test was $<0.0001$, with Cronbach's alpha of 0.804 .

\section{Social Support Scale}

The Social Support Scale (MOS-SSS) - (Sherbourne \& Stewart, 1991) is composed of 19 items, classified on a 5-point Likert scale from 1 to 5: 1 ("never"), 2 ("rarely"), 3 ("sometimes"), 4 ("almost always"), and 5 ("always"). The original MOS was applied to 2,987 participants and five dimensions emerged: material, affective, positive social interaction, emotional, and informational. The adaptation and validation for use in Brazil, by Griep et al. (2005), was carried out with 4,030 college workers. The factor analysis emerged three dimensions: positive social interaction/affective support; emotional/informational support; and material support.

When comparing young and older adult students, it was sought to assess the frequency at which students could count on someone to participate in different daily activities, emphasizing the importance of social support in well-being. Each item measures, on an ordinal scale, the frequency at which the student believes to obtain social support. In this comparison between younger individuals and older adults, although the instrument adapted and validated by Grief et al. (2005) was used, the means of the five dimensions suggested in the study by Sherbourne \& Stewart (1991) were calculated.

\section{Academic Performance}

In this study, the academic performance was represented by the students' performance in college, with the performance coefficient, or index PC, being chosen. In three years, time (August/September, 
2014; August/September, 2015 and August/September, 2016), the first author of this study had access to the academic systems of the institutions that had been studied. On these occasions, the PC of the 326 students (younger individuals and older adults) were collected and compared the evolution of the academic performance of these students.

\section{Procedures}

The project was approved by the University's Ethics Committee. Interviews were scheduled for the application of the instruments, according to the availability of the participants, and they agreed signing the Informed Consent Form (ICF). It was explained that, by signing the term, they would also authorize the information obtained from the questionnaires to be used exclusively for this study, with no identification of the participants. At the end of the data collection procedure, it was clarified that participating in the research would not bring any burden or risk to the participants, nor would they have any benefit from their participation. However, everyone would have the right to quit at any time and stop participating the research.

\section{Data Analysis}

This manuscript is part of a doctoral thesis, where part of the exploratory and confirmatory analysis has already been published. To analyze the differences between the two age groups regarding the influences of Social Skills and Social Support in relation to Academic Performance, the study was carried out in two stages.

(1) The correlations between the averages of the total scale of the Social Support Construct and its dimensions, and between the One-Dimensional Scale of Social Skills and the Performance Coefficients (PC1, PC1 and PC3) of college students in the years 2014, 2015, and 2016, as well as the total PC, were made and analyzed. In view of the notion of normality, measuring Spearman's correlations seemed more appropriate to the study because it is a non-parametric method. The test is applied in situations of inference, in which the distribution of the different populations involved in the study does not need to belong to a specific group of probabilities (Pasquali, 2017).

(2) Subsequently, the multiple hierarchical regression was performed in order to verify whether the independent variables (social support and social skills) would influence the dependent variable (academic performance) and its predictive power. Hierarchical regression is used in confirmatory studies, since this type of analysis seeks to explain the relationship between the variables described in consistent theoretical models, in models that present a set of empirical propositions that already indicate the magnitude and direction of the relationship between variables, but which still require validation (Campos \& Rueda, 2017).

At the end, other additional results are presented, such as the Academic Performance differences between the age groups, through the PCs obtained in the 2014-2016 period.

\section{Results}

The data were analyzed and described below, in order to comply with the objective of this study, which is to analyze the influence of social support and social skills concerning academic performance. Thus, we describe below the results of Spearman's correlations between the study variables and logistic regressions to confirm the hypotheses.

Firstly, the Spearman correlations of the total sample $(N=326)$ and the scale of social support (total and dimensions) with social skills were analyzed. The social support scale dimensions showed strong correlations with the social support general dimension $(p<0.05)$. The social support dimensions, on

6 the other hand, were weakly and strongly correlated. The social skills dimensions were weakly and 
strongly correlated. Table 1 shows that between the social skills and social support constructs, significant positive correlations were revealed in three social support dimensions: affective $(r=0.12 ; p<0.05)$, informational $(r=0.12 ; p<0.05)$ and positive social interaction $(r=0.17 ; p<0.01)$, although these correlations were weak.

Table 1

Spearman correlations of the Social Support Scale and its dimensions, Social Skills Scale, and Academic Performance (without their respective Performance Coefficients PC-1, PC-2 and PC-3)

\begin{tabular}{|c|c|c|c|c|c|c|c|c|c|c|c|c|c|}
\hline Variables & $M$ & $S D$ & 1 & 2 & 3 & 4 & 5 & 6 & 7 & 8 & 9 & 10 & 11 \\
\hline 1. Total Social Support & 4.03 & 0.57 & - & & & & & & & & & & \\
\hline 2. Material Support & 3.76 & 0.75 & $0.63^{* *}$ & - & & & & & & & & & \\
\hline 3. Affective Support & 4.44 & 0.65 & $0.76^{* *}$ & $0.43^{* *}$ & - & & & & & & & & \\
\hline 4. Emotional Support & 3.90 & 0.82 & $0.85^{* *}$ & $0.39^{* *}$ & $0.61^{* *}$ & - & & & & & & & \\
\hline 5. Informational Support & 3.91 & 0.77 & $0.81^{* *}$ & $0.30^{* *}$ & $0.44^{* *}$ & $0.74^{* *}$ & - & & & & & & \\
\hline 6. Positive Social Interaction & 4.23 & 0.74 & $0.76^{* *}$ & $0.31^{* *}$ & $0.58^{* *}$ & $0.47^{\star *}$ & $0.55^{* *}$ & - & & & & & \\
\hline 7. Social Skills & 3.20 & 0.50 & 0.01 & 0.01 & $0.12^{*}$ & -0.08 & $-0.12^{*}$ & $0.17^{* *}$ & - & & & & \\
\hline 8. Performance Coefficient 1 & 6.67 & 1.20 & -0.1 & 0.03 & -0.06 & -0.07 & $-0.14^{*}$ & $-0.12^{\star}$ & -0.04 & - & & & \\
\hline 9. Performance Coefficient 2 & 7.07 & 1.07 & -0.04 & 0.03 & -0.03 & -0.04 & -0.08 & -0.05 & 0.01 & $0.79^{\star *}$ & - & & \\
\hline 10. Performance Coefficient 3 & 7.02 & 1.00 & -0.03 & 0.01 & 0.01 & 0 & -0.05 & -0.06 & -0.07 & $0.68^{* *}$ & $0.74^{* *}$ & - & \\
\hline 11. Academic Performance & 6.92 & 0.99 & -0.06 & 0.03 & -0.03 & -0.04 & -0.1 & -0.09 & -0.02 & $0.92^{\star *}$ & $0.93^{\star \star}$ & $0.88^{* *}$ & - \\
\hline
\end{tabular}

Note: ${ }^{*} p<0.05 ;{ }^{* *} p<0.01 ; N=326$. Academic performance was composed of the average of the three performance coefficients divided by 3 . M: Mean; SD: Standard Deviation.

Regarding academic performance, the three PC measures (PC1, PC2 and PC3) showed strong correlations with each other, as well as with the total PC (PC mean values). PC1 had weak significant correlations with the information support $(r=0.14 ; p<0.05)$ and positive social interaction dimensions $(r=0.12 ; p<0.05)$ of social support. Both PC2 and PC3 did not show any significant correlation with the study variables $(p>0.05)$. This seems to indicate that social support (informational and positive social interaction) was a relevant construct at the beginning of the course, or when entering college. Table 1 shows the correlations specified above.

Using hierarchical multiple regression, several tests were performed: regression with total PC for social support, with and without interaction with age; regression with total PC for social skills, with and without interaction with age. The process was performed separately for each of the variables and for both age groups, with and without interaction with age, always depending on the total PC or total performance.

In the performed regressions, when the centered averages of the variables of social support with social skills were inserted, but no statistical significance was observed, so the two constructs were not predictors of total PC. However, when the restraint was applied to age, the results obtained indicate that the model was significant for younger people, explaining $11.7 \%$ of the academic performance dependent variable $\left(R^{2} \Delta=0.117 ; F=2.063\right.$, value $\left.p=0.021 ; p<0.05\right)$. The informational support $(\beta=2.33 ; p<0.01)$ and material support $(\beta=1.88 ; p<0.05)$ variables had a positive predictive power for the younger age group. In other words, it can be said that the greater the material and informational support that young college students have, the greater their academic performance. However, a positive social interaction $(\beta=-1.68 ; p<0.05)$ had a negative predictive power, that is, the greater the positive social interaction for young people, the lower the academic performance (Table 2 ).

As for the group of older adult college students, Table 3 highlights that, for older adult students, only the material support dimension $(\beta=1.22 ; p<0.05$ ) obtained positive and significant significance. In other 
words, it can be said that the greater the material support for older adult college students, the greater their academic performance.

In addition to the results of the existing correlations for testing the hypothesis and of the hierarchical regressions to prove the influence of the social support and social skills variables on performance, some complementary analyses were carried out:

Table 2

Regression of the Social Support variable and its dimensions, and the Social Skills variable with the academic performance of younger students

\begin{tabular}{lccccc}
\hline Variables & $\beta$ & Standard Error & $\beta$ & $t$ & $p$ \\
\hline Material & 0.141 & 0.055 & 1.88 & 2.564 & $0.010^{* *}$ \\
Affective & 0.105 & 0.090 & 1.08 & 1.171 & 0.243 \\
Emotional & -0.121 & 0.080 & -1.70 & -1.520 & 0.130 \\
Informational & 0.175 & 0.080 & 2.33 & 2.174 & $0.031^{*}$ \\
Positive social interaction & -0.137 & 0.066 & -1.68 & -2.087 & $0.038^{*}$ \\
Social skills & 0.096 & 0.079 & 0.68 & 1.217 & 0.225
\end{tabular}

Note: ${ }^{*} p<0.05 ;{ }^{* *} p<0.01 ; N=200$. Dependent variable: total PC (performance). $\beta$ : Beta Coefficient; t: $t$ Statistic.

Table 3

Regression of the variables Social Support and its dimensions, and Social Skills with the academic performance of older adult students

\begin{tabular}{lccccc}
\hline Variables & $\beta$ & Standard Error & $\beta$ & $t$ & $p$ \\
\hline Material & 0.122 & 0.076 & 1.66 & 1.605 & $0.015^{*}$ \\
Affective & 0.100 & 0.095 & 1.02 & 1.052 & 0.137 \\
Emotional & 0.171 & 0.080 & 1.40 & 2.138 & 0.110 \\
Informational & 0.126 & 0.060 & 2.12 & 2.100 & 0.085 \\
Positive social interaction & -0.156 & 0.076 & -1.24 & -2.053 & 0.135 \\
Social skills & 0.085 & 0.079 & 0.38 & 1.076 & 0.184 \\
\hline
\end{tabular}

Note: ${ }^{*} p<0.05 ; N=126$. Dependent variable: total PC (performance). $\beta$ : Beta Coefficient; t: $t$ Statistic.

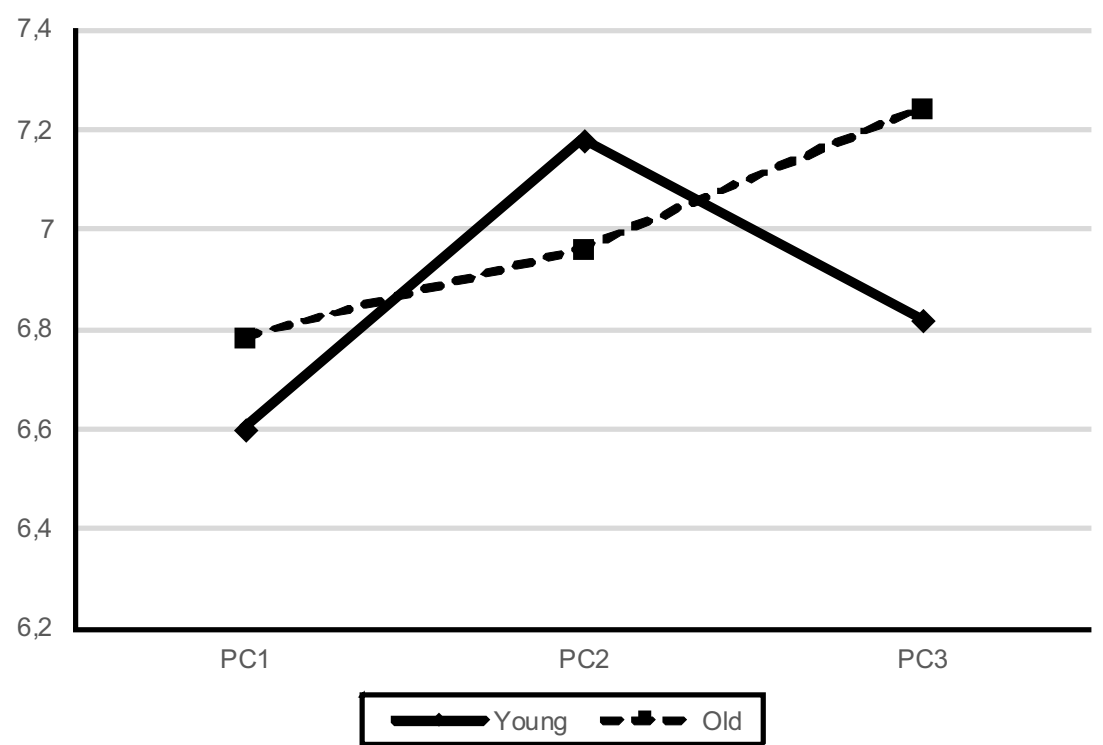

Figure 1. Evolution of average academic performance over the evolution of the Performance Coefficients of the young and the old students. Note: PC1: In the first year of college (freshman year); PC2: In the second year of college (sophomore year); and PC3: In the third year of college (junior year). 
(1) The average age of the older adult students was 64 years, while the average for younger students was 22 years. At the beginning of the research, the oldest participant was 82 years old and the youngest was 18 years old.

(2) There was an effective evolution in the average performance of older adult students over the three-year period; which did not happen with the younger students: older adults (PC1 $=6.78$; $P C 2=6.94$; $P C 3=7.26)$ and younger individuals ( $P C 1=6.60 ; P C 2=7.15 ; P C 3=6.84)$, as can be seen in Figure 1 .

(3) Among the 10 (ten) best total average academic performances (total PC), 5 (five) were men and 5 (five) women, being 9 (nine) younger individuals and only 1 (one) older adult.

(4) Among the 10 (ten) worst average total academic performances (total PC), 6 (six) were men and 4 (four) women, all of whom were younger individuals.

\section{Discussion}

The study served its purpose of investigating whether social support and social skills could influence the academic performance of older adult college students. Its results highlighted the relevance of social support, and the consistency of the theory regarding its scale and dimensions (Sherbourne \& Stewart, 1991). Most of the research items focused on the essential aspects of social support and the perceived availability of some components of functional support.

Most of the older adults in this study reported a high level of perceived social support, confirming data from previous studies (Griep et al., 2005; Zanini \& Peixoto, 2016; Zanini, Verolla-Moura, \& Queiroz, 2009). The fact that people realize that there are positive relations with their family can be helpful in the most significant moments of life. This is an especially important factor for maintaining the quality of life of older adults (Anjos et al., 2015), which were corroborated by Hill (2016), who stated that emotional social support was predictive of a better quality of life and a lower rate of depression.

The positive social interaction dimension, that is, having someone to relax with and perform pleasurable activities, should be encouraged, especially among older adult students, considering that opportunities for social interactions are reduced at this stage of life (Oliveira, Leal, \& Oliveira, 2018). This result is corroborated by the study of Brito and Pavarini (2012), where they state that emotional support has a protective effect for older adults and such an effect would lead to feelings of involvement and social interaction, providing greater meaning in the lives of these individuals. Li, Ji, and Chen (2014), in a study with 700 Chinese older adults, demonstrated that the support of family and friends plays different roles in the emotional well-being of this population. The positive affection of friends (based on personal and selective interests) is even more impacting than family support.

Significant differences were identified between younger individuals and older adult students with regard to perceived social skills, corroborating other studies (Carneiro \& Falcone, 2013). Younger students $(M=3.38 ; S D=0.46)$ showed, in general, higher scores on perceived social skills than older adults $(M=2.90 ; S D=0.42) ; t=9.70 ; p<0.001$. The explanation for this difference may be due to the removal of older adults from lecturing and social relationships; and this refers to the importance of intergenerational relationships and activities within and outside the academic environment (Rocha \& Carrera, 2011). However, the performed hierarchical regression did not identify the influence of social skills on the performance of either older adults or younger students, at least due to their academic assessments over three years. Despite this result, perhaps social skills can favor students more when they enter college, as highlighted by Soares, Leme, Nogueira, Maia, and Lima (2016), in view of the requirement for a differentiated repertoire, higher levels of responsibility and autonomy for students. 
It is important to emphasize that older adults showed greater consistency in their academic results, with the upward curve of the group's results, as seen in Figure 1, which seems to corroborate the idea that, when they are interested in something, they imprint their will and, associated with resilience, seem more apt to success (Ayala \& Manzano, 2018). In young individuals, the variety of interests and opportunities makes them scatter among different goals.

The first hypothesis was confirmed in relation to the predictive power of the three social support dimensions (material, informational, and positive social interaction) in the younger individual's group, although, in the latter case, a greater positive social interaction predicts a negative performance. This can be explained due to the fact that, in their senior year, students need less distraction and more focus and dedication to their studies, as they are about to go through their final exams. On the other hand, for older adult college students, these variables did not influence academic performance, only at the beginning of the course, in other words, in the college setting. In this regard, Fonseca (2016) argues that older adults already have the necessary tools for good coexistence in new environments, obtained either through professional or life experiences.

Material, informational and social interaction supports were more necessary for younger students throughout the study period. Perhaps, for older adults, what is most important is the maintenance of social support acquired throughout life or even the challenge of replacing the loss of that support with new social relations. These questions can be investigated in a future qualitative study.

As for the second hypothesis, in view of the relevance of social skills, the research did not show significant results, as the regression analysis did not demonstrate that there was a predictive strength of social skills for their academic performance. Nevertheless, it is a fact that students use their particular skills to achieve better academic performances; therefore, educational institutions must strive to recognize and assess their needs based on the skills developed (Souza \& Dourado, 2015). It is crucial to create more welcoming spaces in which college students, young and old, can improve their skills and develop themselves.

College performance analysis showed greater consistency in the academic performance of older adult students. Although the best results were for younger college students, older adults maintained an increasing performance curve over the three years. Perhaps this result corroborates with the dictum that older adults have less interests and perform fewer activities simultaneously, compared to the countless interests and activities developed by younger people. However, the former, as a rule, know what they want and when they commit to doing something they dive right in with their determination. Investing in learning strategies directed to the priority interests of the two age groups can generate equally relevant results in their cognitive development.

This research presents recommendations for future studies, in view of the limitations to be faced. It is important to highlight the non-confirmation of the prediction hypothesis of social skills for academic performance. Therefore, we have suggestions both with regard to the participants and to the instrument for measuring social skills.

With regard to the participants, we suggest the replication of this model with a large sample, which is closer to the profile of college students from Brazilian institutions, both in relation to older adults and younger individuals, and may present greater statistical robustness and a greater spectrum of social skills. It is also essential to investigate gender differences and similarities.

As for the social skills instrument, it should be remembered that the analysis factor showed low factor loads (less than $<0.40$ ) and that several items were excluded because they did not have good psychometric properties. Thus, the final instrument was reduced to 13 items, being aggregated in the one-dimensional structure.

Despite being an abbreviated version similar to that presented by Leme et al. (2017), which presented four dimensions, future studies may use the new version of the Social Skills Inventory (SSI II) (Del Prette, Z. \& 
Del Prette, A., 2018) that was not available for use at the time of data collection for this study. An alternative for those who want to delve deeper into this construct is the search for other Social Skills scales, such as the Social Skills Rating System - Student Form (SSRS-S) (Gresham \& Eliot, 1990), which was adapted and validated for a sample with 573 Portuguese teenage students (Mota, Matos, \& Lemos, 2011), resulting in the extraction of the cooperation dimension, obtaining good results.

New studies may also verify the possibility of using the Social Competence construct - defined as effectiveness in social interaction. Social competence is an organizing construct, with transactional, context-dependent, and objective-specific characteristics (Rose-Krasnor, 1997). According to this author, the operational definition of social competence implies four approaches to its operational definition that include social skills, sociometric status, relationships, and results. The instrument that assessed social competence was the Multidimensional Social Competence Scale used with children with autism problems. In this sense, it is recommended to use the scale adapted by Trevisan, Tafreshi, Slaney, Yager, and Iarocci (2018) in a study with 1,178 healthy Canadian college students.

Another perceived limitation was that the study did not include other constructs and variables that could better explain the differences and similarities in academic performance between younger individuals and older adults. In addition, some variables can serve as mediators in the explanatory model of academic performance and quality of life, such as self-esteem and its mediating role in the relationship between social support and academic results in Chinese students (Li, Han, Wang, Sun, \& Cheng, 2018). Regarding the regression technique, previous studies have already shown that interactions are not easily detectable in the use of moderated regression (Gordon, 2015). Therefore, it is suggested that future studies use the structural equation modeling.

\section{Conclusion}

With the increase in age diversity, the question of how younger individuals and older adult students have been perceived by each other arises. It is necessary to know what are the main stereotypes, how they can be faced with the increase of age diversity in Education. Thus, the question we ask is whether this age diversity could produce a positive environment among age groups.

In this study, it is important to highlight the essential differences observed between the age groups, in regard to both social support and social skills, although social support has proved to be more important for younger people, in relation to academic performance. For a better understanding of these differences, specifically in relation to performance, a deeper and longitudinal examination is imperative.

In addition to the age differences between the groups, future studies must observe the female and male behavior in relation to these constructs between groups. The study also reminds us of the relevance of a social skills course to be promoted by universities in their social actions with the community. This could be done in an intergenerational way, creating opportunities to break prejudices between generations as well as the search for intergenerational social support.

It is concluded, in view of the problems related to ageing, that the study represents an important contribution in the field of gerontology, education, and social psychology. It is essential to face the challenge of ageing with the maintenance of intergenerational relations between college students, which must be further explored and taken care of. Therefore, given the complexity of the study, it is recognized that there is a need to incorporate other constructs and variables that may contribute to the understanding of academic performance among younger individuals and older adult students. Above all, carrying out interventions with both age groups to improve intergenerational relationships and academic performance. 


\section{Contributors}

LEITE, S. V. contributed to the conception and design, data collection, data analysis and interpretation, data discussion, review, and final approval of the article. FRANÇA, L. H. F. P. contributed to the conception and design, data analysis and interpretation, data discussion, review, and final approval of the article. LEITE, S. B. F. contributed to the data collection, data analysis and interpretation, and data discussion.

\section{References}

Ambiel, R. A. M., Pereira, C. P. S., \& Moreira, T. C. (2015). Produção científica em avaliação psicológica no contexto educacional: enfoque nas variáveis socioemocionais. Avaliação Psicológica, 14, 339-346. https://doi.org/10.15689/ ap.2015.1403.05

Anjos, K. F., Boery, R. N. S., Pedreira, L. C., Vilela, A. B. A., A., Santos, V. C., \& Santa Rosa, D. O. (2015). Associação entre apoio social e qualidade de vida de cuidadores familiares de idosos dependentes. Ciência \& Saúde Coletiva, 20(5), 1321-1330.

Ardelt, M. J. (2010). Are older adults wiser than college students? a comparison on two age cohorts. Journal of Adult Development, 17(4), 193-207.

Ayala, J. C., \& Manzano, G. (2018). Academic performance of first-year University students: the influence of résilience and engagement. Higher Education Research \& Development, 37(7), 1321-1335. https://doi.org/10.1080/0729436 0.2018 .1502258

Bandeira, M., Rocha, S., Freitas, L., Del Prette, Z., \& Del Prette, A. (2006). Habilidades sociais e variáveis sociodemográficas em estudantes de ensino fundamental. Psicologia em Estudo, 11, 541-549.

Bauman, Z. (2011). 44 cartas do mundo líquido moderno. Rio de Janeiro: Jorge Zahar.

Bonaco, R. A., Costa, C. E., Gon, M. C. C., \& Zamignani, D. R. (2019). Perseguindo um modelo experimental para transtornos de personalidade: relatos iniciais de um grupo de pesquisa. In J. C. Luzia, J. Gamba, N. Kienen, \& S. R. S. A. Gil (Eds.), Psicologia e análise do comportamento: pesquisa e intervenção (pp. 68-79). Londrina: Universidade Estadual de Londrina.

Brito, T. R. P., \& Pavarini, S. C. I. (2012). The relationship between social support and functional capacity in elderly persons with cognitive alterations. Revista Latino-Americana de Enfermagem, 20(4), 677-684.

Campos, M. I., \& Rueda, F. J. M. (2017). Regressão linear e quadrática: análises comparativas de efeito em medidas do comportamento organizacional. Estudos de Psicologia (Natal), 22(2), 225-234.

Carneiro, R. S., \& Falcone, E. M. O. (2013). O desenvolvimento das habilidades sociais em idosos e sua relação na satisfação com a vida. Estudos de Psicologia, (Natal), 18(3), 517-526.

Cerda, G., Pérez, C, G., C., Navarro, J. I., Aguilar, M., Casas, J. A., \& Aragón, E. (2015). Explanatory model of emotionalcognitive variable in school mathematics performance: a longitudinal study in primary school. Frontiers in Psychology, 6, 1-10. https://doi.org/10.3389/fpsyg.2015.01363

Chaves, L. B., Souza, T. F., Silva, M. V. C., Oliveira, C. F., Lipp, M. E. N., \& Pinto, M. L. (2016). Estresse em universitários: análise sanguínea e qualidade de vida. Revista Brasileira de Terapias Cognitivas, 12(1), 20-26. https://doi. org/10.5935/1808-5687.20160004

Del Prete, Z. A. P., \& Del Prete, A. (2018). Inventário de Habilidades Sociais 2 (IHS2-Del-Prette): kit completo. São Paulo: Casa do Psicólogo.

Del Prette, A., \& Del Prette, Z. A. P. (2018). A relação entre habilidades sociais e análise do comportamento: história e atualidades. In N. Kienen, S. R. S. A. Gil, J. C. Luzia, \& J. Gamba (Orgs.), Análise do comportamento: conceitos e aplicações a processos educativos clínicos e organizacionais (pp. 39-53). Londrina: UEL. Recuperado de http://www. uel.br/pos/pgac/publicacoes/

Del Prette, Z. A. P., \& Del Prete, A. (2001). Inventário de habilidades sociais: manual de aplicação, apuração e interpretação. São Paulo: Casa do Psicólogo.

Del Prette, Z. A. P., \& Del Prette, A. (2009). Avaliação de habilidades sociais: bases conceituais, instrumentos e procedimentos. In A. Del Prette \& Z. A. P. Del Prette (Orgs.), Psicologia das habilidades sociais: diversidade teórica e suas implicações (pp. 187-229). Petrópolis: Vozes. 
Del Prette, Z. A. P., Del Prette, A., \& Barreto, N. C. M. (2006). Treinamento em habilidades sociais em grupo de estudantes de Psicologia: avaliando um programa de intervenção. In M. Bandeira, Z. A. P. Del Prette, \& A. Del Prette (Orgs.), Estudos sobre habilidades sociais e relacionamento interpessoal (pp. 217-234). São Paulo: Casa do Psicólogo.

Eisenhower, A., Baker, B., \& Blacher, J. (2007). Early student-teacher relationships of children with and without intellectual disability: contributions of behavioral, social and self-regulatory competence. Journal of School Psychology, 45(4), 363-383.

Fernandes, L. M., Leme, V. B. R., Elias, L. C. S., \& Soares, A. B. (2018). Preditores do desempenho escolar ao final do ensino fundamental: histórico de reprovação, habilidades sociais e apoio social. Temas em Psicologia, 6(1), $215-228$. http://dx.doi.org/10.9788/TP2018.1-09Pt

Fonseca, S. C. (2016). O envelhecimento ativo e seus fundamentos (1a ed.). São Paulo: Portal Edições.

Gordon, R. (2015). Regression analysis for the social sciences (2nd ed.). New York: Taylor \& France. http://doi. org/10.4324/9781315748788

Gresham, F. M., \& Elliot, S. N. (1990). Social skills rating system manual. Circle Pines: American Guidance Service.

Griep, R. H., Chor, D., Faerstein, E., Werneck, G. L., \& Lopes, C. S. (2005). Validade de constructo de escala de apoio social do Medical Outcomes Study adaptada para o português no estudo pró-saúde. Cadernos de Saúde Pública, 21(3), 703-714.

Hill, E. M. (2016). Quality of life and mental health among women with ovarian cancer: examining the role of emotional and instrumental social support seeking. Psychology, Health \& Medicine, 21(5), 551-561. http://doi.org/10.1080/1 3548506.2015.1109674

Leite, S. V., \& França, L. H. P. F. (2018). O método quantitativo na análise da estrutura interna do inventário de habilidades sociais e sua aplicação no ambiente de jovens e idosos dos cursos de direito. In M. M. Peixinho, C. B. Abreu, \& A. R. C. Cunha (Orgs.), Diretrizes de metodologia da pesquisa jurídica (pp. 105-120). Rio de Janeiro: Lumen Juris.

Leme, V. B. R., Valentini, F., Campos, J. R., Del Prette, A., \& Del Prette, Z. A. P. (2017). Psychometric properties of the brief version of the Social Skills Inventory for Adolescents. Spanish Journal of Psychology, 20, e23. https://doi.org/10.1017/ sjp. 2017.29

Li, H., Ji, Y., \& Chen, T. (2014). The roles of different sources of social support on emotional well-being among chinese elderly. Plos One, 9(3), e90051. https://doi.org/10.1371/journal.pone.0090051

Li, J., Han, X., Wang, W., Sun, G., \& Cheng, Z. (2018). How social support influences university students' academic achievement and emotional exhaustion: the mediating role of self-esteem. Learning and Individual Differences, 61(1), 120-126. https://doi.org/10.1016/j.lindif.2017.11.016

Mertoglu, M., \& Aydin, O. (2012). An analysis of the relationship between the lives of the primary-secondary school students regarding domestic violence at home and their academic success. Procedia-Social and Behavioral Sciences, 55(5), 1233-1242.

Mirabelli, S. C. S. (2015). Educação para o longeviver: nuances e dimensões da ensinagem. Anais da Semana de Gerontologia e I Simpósio Internacional de Gerontologia Social Longevidade como oportunidade: Práxis Contemporâneas, São Paulo, pp. 99-104.

Morrison, J. (2015). Technical adequacy of the student protective factors screening scale (SPF-7) as a universal screening tool. Psychology, 6, 817-832. http://dx.doi.org/10.4236/psych.2015.67081

Mota, C. P., Matos, P. M., \& Lemos, M. S. (2011). Psychometric properties of the Social Skills Questionnaire Portuguese adaptation of the Student Form (grades 7 to 12). Spanish Journal of Psychology, 14(1), 486-499. https://doi.org/10.5209/ rev_SJOP.2011.v14.n1.44

Neri, A. L. (2014). Palavras-chave em Gerontologia (4a ed.). Campinas: Editora Alínea

Oliveira, S. A. S., Leal, W. S, \& Oliveira, S. F. P. (2018). The game is not over: metodologias de ensino e aprendizagem em língua portuguesa, com vistas ao desafio e à autonomia do estudante. Revista Eletrônica de Letras, 11(1), 1-85.

Organização das Nações Unidas. (2003). Plano de ação internacional contra o envelhecimento, 2002. Brasília: Secretaria Especial dos Direitos Humanos (Série Institucional em Direitos Humanos, Vol.1).

Pasquali, L. (2017). Psicometria: teoria dos testes na psicologia e na educação. Petrópolis: Vozes.

Roberts, S., \& Dunbar, R. (2015). Managing relationship decay. Human Nature, 26(4), 426-450. https://doi.org/10.1007/ s2110-015-9242-7

Rocha, J. F., \& Carrera, K. (2011). Formação ética para a cidadania: reorganizando contingências na interação professor-aluno. Revista Semestral da Associação Brasileira de Psicologia Escolar e Educacional, 15(2), $221-230$. 
Rose-Krasnor, L. (1997), The nature of social competence: a theoretical review. Social Development, 6(1), 111-135. https:// doi.org/10.1111/1467-9507.1997.ep11633447

Rudnick, A., McEwan, R. C., Pallaveshi, L., Wey, L., Lau, W., Alia, L., \& Volkenberg, L. V. (2013). Integrating supported education and supported employment for people with mental illness: a pilot study. International Journal of Psychosocial Rehabilitation, 18(1), 5-25.

Sherbourne, C. D., \& Stewart, A. L. (1991). The MOS social support survey. Social Science \& Medicine, 32(6), 705-714.

Soares, A. B., Leme, V. B. R., Nogueira, C. C., Maia, F. A., \& Lima, C. A. (2016). Situações interpessoais: o que dizem os estudantes universitários? In A. B. Soares, L. Mourão, \& M. M. P. E. Mota (Orgs.), Estudante universitário brasileiro: características cognitivas, habilidades relacionais e transição para o mercado de trabalho (1a ed., pp. 115-126). Curitiba: Appris Editora.

Souza, S. C., \& Dourado, L. (2015). Aprendizagem baseada em problemas (ABP): um método de aprendizagem inovador para o ensino educativo. Holos, 31(5), 182-200. https://doi.org/10.15628/holos.2015.2880

Stephens, N. M., Fryberg, S. A., Markus, H. R., Johnson, C. S., \& Cavarrubias, R. (2012). Unseen disadvantage: how American universities' focus on independence undermines the academic performance of first-generation college students. Journal of Personality and School Psychology, 102(6), 1178-1197. https://doi.org/10.1037/a0627143

Sultan, S., \& Rashid, S. (2015). Perceived social support mediating the relationship between perceived stress and job satisfaction. I-Manager Journal on Educational Psychology, 8(3), 36-42.

Thurber, C., \& Walton, E. (2012). Homesickness and adjustment in university students. Journal of American College, 60(5), 415-419. https://doi.org/10.1080/07448481.2011.673520

Trevisan, D., Tafreshi, D., Slaney, K. L., Yager, J., \& larocci, G. (2018). A psychometric evaluation of the Multidimensional Social Competence Scale (MSCS) for young adults. Plos One, 13(11), e0206800. https://doi.org/10.1371/journal. pone. 0206800

Wiles, J. L., Leibing, A., Guberman, N., Reeve, J., \& Allen, R. E. S. (2012). The meaning of "aging in place" to older people. Gerontologist, 52(3), 357-366.

Zanini, D. S., \& Peixoto, E. S. (2016). Social support scale (MOS-SSS): analysis of the psychometric properties via item response theory. Paidéia, 26(65), 359-368. https://doi.org/10.1590/1982-4327665201612

Zanini, D. S., Verolla-Moura, A., \& Queiroz, I. P. A. R. (2009). Social support: validity aspects of the construct in under graduation Student. Psicologia em Estudo, 14(1), 195-202.

Received: October 22, 2019

Final version: July 29, 2020

Approved: September 28, 2020 